\title{
乳腺細胞診および画像診断における 組織型推定の現状と問題点
}

\author{
ブレストピアなんば病院 \\ 難波清
}

\begin{abstract}
近年のわが国における乳癌の診断学の進歩は著しい. 視触診から切開生検という従来の診断過程 は，画像診断からより非侵襲的な細胞診，針生検に置換されてきた。良悪性の鑑別診断のみならず 治療や経過観察の決定までもが細胞診に求められるようになり，その診断学は複雑高度化した。そ の中で, 乳腺腫崵の病理組織型を形態学の基本として, 画像診断と細胞診断の両者が組織型の推定 を念頭に置いてアプローチするという考え方が重要性を増している.

ブレストピアの超早期乳癌診断システムにおける約 12,000 件の乳腺細胞診と画像診断や病理診 断の経験をもとに, 臨床医の立場から画像診断と細胞診における組織型推定の現状と問題点を具体 的に検討した. 形態パターン分類から組織型を念頭に置いた画像診断を行う. 得られた組織型推定 をもとに, 検体採取の工夫や細胞検査士への情報提供, フィードバックなどを行うことで, 画像, 細胞両者の診断精度の向上が達成できる, そのためには, 相互の往来のある診断システム作りが重 要である.
\end{abstract}

Key words: Cytlogy_-Fine-needle aspiration cytology-Breast cancer-Histopathological type- - Image diagnosis

\section{I. はじめに}

欧米に大きく遅れたが近年わが国でも乳癌の診断学 は急速に進歩し，視触診から切開生検という従来の診 断過程は，画像診断から細胞診という侵襲のより小さ いプロセスに置き換えられるようになってきた。乳腺 疾患の良悪性の鑑別診断は, 病理組織診断の中でもき わめて困難な領域があり，それを細胞診で置換するこ とはかなり困難ではないかと思われる。しかし, 細胞 診が, 病理組織診断の補助診断としての位置付けを確

Present status and problems in predicting the histology of breast cancer using imaging diagnosis

Kiyoshi NAMBA, M.D.

Breastopia Namba Hospital

論文別刷請求先 テ 880-0052 宮崎市丸山 2 の 112 の 1 ブレ

ストピアなんば病院 難波 清

平成 13 年 1 月 15 日受付

平成 13 年 6 月 15 日受理
立するためには, 少なくともその病変の本質に密接に 迫り, 細胞診の診断能を向上させるための努力が必要 になる。乳腺腫瘍の病理組織診断は構造異型を非常に 重要視する. 幸いにも細胞診は 3 次元的な評価が可能 であることから, 構造異型の評価や画像診断のイメー ジとの対比を行うのに有利である.したがって, 細胞 診断では，ただ闇雲に良悪性の判定を行うのでなく， 3 次元的イメージから病理組織型を類推しながら, 細 胞像を読んで可能な限り良悪性を判定することが重要 になった。

今回, ブレストピアの超早期乳癌診断システム ${ }^{1,2}$ で実施した約 12,000 件 (8 年 7 カ月間, 乳癌症例約 1,160 件を含む) の乳腺細胞診やマンモグラフィ, 超 音波検査, MRI, 乳管鏡（乳管内視鏡, mammoscopy）などの画像診断の豊富な経験をもとに, 臨床 医の立場から画像診断と細胞診における組織型推定の 現状と問題点を実際の症例を用いて具体的に明らかに する。 


\section{II. ブレストピアにおける乳腺細胞診の現状}

ブレストピアでは 1991 年 6 月の開院以来，院内に 病理細胞診検查室を設置し，細胞検查士を配置し，積 極的に細胞診を行ってきた。乳腺細胞診の方法として は, 穿刺吸引細胞診 (FNAC), 分泌物直接塗抹細胞 診, 分泌物洗浄細胞診, 擦過細胞診などがある. 最近 では針生検 (core needle biopsy, CNB) ${ }^{3)}$ やマンモ トーム ${ }^{4,5}$ の導入と進歩に伴い, 針生検施行例では FNACの代わりに標本の touch smear 細胞診なども 試みている(Fig. 1).

細胞診を種類別にみると, FNACが 7,498 件（全 体の $65 \%$ ）と最も多く，次いで分泌物直接塗抹細胞 診 2,335 件 $(20 \%)$, 洗浄細胞診 1,312 件 (11\%)，擦 過細胞診 78 件 $(1 \%)$, 最近始めた針生検標本を用い たタッチスメア細胞診 316 例のような分布がみられた (Fig. 2).

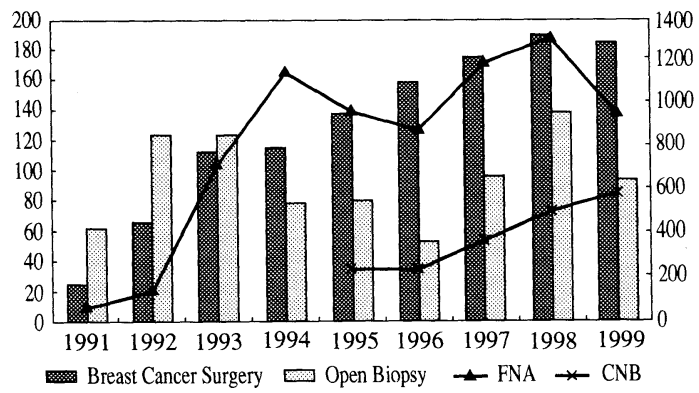

Fig. 1 Annual trends in surgery for breast cancer, open biopsy, FNAC and CNB at Breastopia.

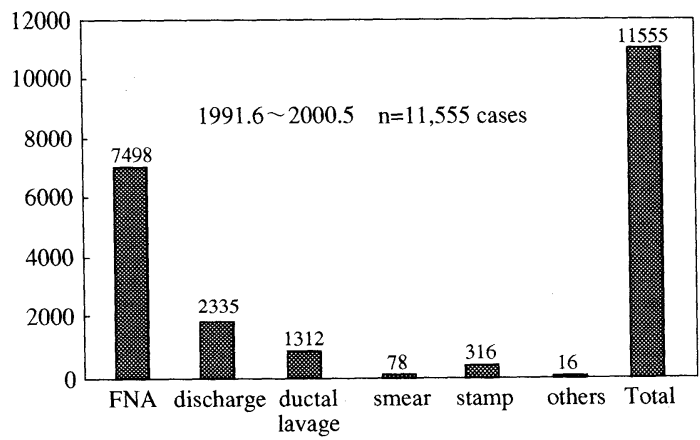

Fig. 2 Present distribution of cytological examinations.

\section{III. 乳腺画像診断の概要 : 組織型推定 に関して}

乳腺疾患の画像診断の方法には，マンモグラフィ (乳房専用 $\mathrm{X}$ 線装置, mammography, MMG), 超 音波検査装置 (ultrasound scanner), 乳管鏡 (乳管 内視鏡， mammoscopy）の他に，最近では MRI（核 磁気共鳴装置）などがある。これらのモダリティはお のおの, その原理, 機器の形態, 撮影方法, 等々, 異 なる特徵を有しており, 専門領域ではこれら 4 つのモ ダリティを駆使して乳癌の診断や治療方法の決定など に役立てている。

基本的には，マンモグラフィと超音波検査は両側乳 房に対して行っており，ブレストピアのような乳腺疾 患専門病院では一般検査として機能している.MRI は，主に一般画像検査で良悪性の判定困難な症例や乳 癌の乳房内での広がり診断に活用している。さらに， 血性の乳頭分泌が認められたら乳管造影や乳管鏡など も行い, 診断精度を高めている（Fig. 3).

画像診断を行う上で最も大事にしていることは，常 に病理組織型を念頭に置いて画像を評価することであ る. 良悪性の鑑別診断は組織型診断が大前提であるわ けだから，このような姿勢は当然のことである。

\section{IV. 乳腺腫瘍の組織型分類}

乳癌を最も単純に分けると，塊（かたまり）の癌と 管（くだ）の癌に大別される.さらにその発育進展様 式から分けると, 乳管外浸潤型, 乳管内進展型とその 中間型の 3 つに大別できる. そして, すべての乳腺腫 瘍を病理組織学的形態パターンから分類したものが, WHO 分類 ${ }^{6)}$ 臨床 - 病理乳癌取扱い規約分類 ${ }^{7)}$ (Table 1) である. 両者の最大の相違点は, 前者でひ とまとめにされている浸潤性乳管癌が後者では乳頭腺

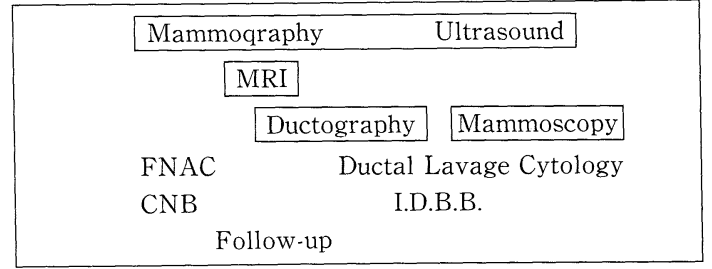

Fig. 3 Comprehensive diagnosis of breast cancer at Breastopia. 
Table 1 Histological. Classification of breast tumors : Clinical and pathological rules for the treatment of breast cancer, 13th Ed.

\begin{tabular}{|c|c|c|c|}
\hline $\begin{array}{l}\text { I. Epithelial tumors } \\
\text { A. Benign } \\
\text { 1. Intraductal papilloma } \\
\text { 2. Adenoma of the nipple } \\
\text { 3. Adenoma } \\
\text { B. Malignant (carcinoma) } \\
\text { 1. Noninvasive ca. } \\
\text { a. Noninvasive ductal ca. } \\
\text { b. Noninvasive lobular ca. } \\
\text { 2. Invasive ca. } \\
\text { a. Invasive ductal ca. } \\
\text { a 1. Papillotubular ca. } \\
\text { a 2. Solid-tubular ca. } \\
\text { a } 3 . \text { Scirrhous ca. }\end{array}$ & $\begin{array}{l}\text { b. Special types } \\
\text { b 1. Mucinous ca. } \\
\text { b 2. Medullary ca. } \\
\text { b 3. Invasive lobular ca. } \\
\text { b 4. Adenoid cystic ca. } \\
\text { b } 5 . \text { Squamos cell ca. } \\
\text { b 6. Spindle cell ca. } \\
\text { b } 7 . \text { Apocrin ca. } \\
\text { b } 8 . \text { Ca. with cartillageous } \\
\text { and/or osseous metaplasia } \\
\text { b } 9 . \quad \text { Tubular ca. } \\
\text { b 10. Secretory ca. } \\
\text { b 11. Others } \\
\text { 3. Paget's disease }\end{array}$ & $\begin{array}{l}\text { II. Mixed connective tissue } \\
\text { \& epithelial tumors } \\
\text { A. Fibroadenoma } \\
\text { B. Phyllodes tumor } \\
\text { (Cystosarcoma phyllodes) } \\
\text { C. Carcinosarcoma } \\
\text { III. Nonepithelial tumors } \\
\text { A. Stromal sarcoma } \\
\text { B. Soft tissue tumor } \\
\text { C. Lymphoma \& } \\
\text { D. Others }\end{array}$ & $\begin{array}{l}\text { V. Unclassified tumors } \\
\text { V. Mastopathy } \\
\text { (Fibrocystic disease, } \\
\text { Mammary dysplasia) } \\
\text { V. Tumor-like lesions } \\
\text { A. Duct ectasia } \\
\text { B. Inflammatory } \\
\text { pseudotumor } \\
\text { C. Hamartoma } \\
\text { D. Gynecomastia } \\
\text { E. Accessary } \\
\text { mammary gland } \\
\text { F. Others }\end{array}$ \\
\hline
\end{tabular}

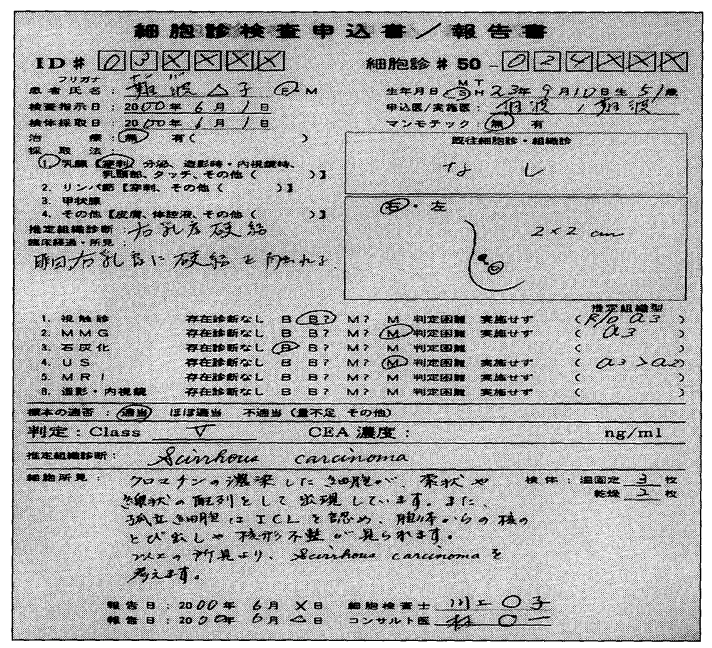

Fig. 4 Application and reporting form for breast cytological examination at Breastopia.

管癌, 充実腺管癌, 硬癌の 3 型に分けられていること である.その主な理由は元来予後との相関であった が，3つの組織形態パターンがより精度の高い画像診 断や細胞判定に結びつくことが分かるようになり，診 断学上の重要性が認識されるようになった。さらに, 良悪性の鑑別診断においても，多くの組織型を整理し て認識し，視触診や画像診断，さらに細胞診でみえる ものが組織分類上どれに該当するのかを常に念頭に置 いてアプローチすることが求められるようになった。 そういう考え方を元に作成したブレストピアの乳腺細 胞診申込書および報告書を示す (Fig. 4).
Table 2 Classification of breast tumors in image diagnosis-infer the histologic type from image diagnosis

\begin{tabular}{l}
\hline Tumor-forming Type \\
$\cdot$ localized tumor \\
$\cdot$ invasive tumor \\
$\cdot$ multiple tumor \\
$\bullet$ Non-tumor Type \\
$\cdot$ diffuse non-tumor \\
$\cdot$ Non-tumor with micricalcifications \\
\hline
\end{tabular}

\section{V. 画像診断から細胞診へ}

\section{1. 組織型推定}

乳腺腫瘍を正しく診断するためには, 組織型を熟知 しておくことの重要性は前述した通りである。ここで は，画像診断の形態パターンを腫瘤形成性と腫瘤非形 成性の 2 つに分類し,さらに形態パターンにより覀分 類し (Table 2),さらに組織型と対応させてみた (Fig. $5 \mathrm{a} \sim$ d). 予測に違わず， 1 対 1 対応のものは少 なくかなり複雑である。病理組織型を熟知していて も，画像のみで正しく診断することが困難な場合が 多々ある。とくに，腫瘍が早期で小さくなるほど，ま た画像の特徴が良性特有のものを示すほど診断困難な ケースは増えていく，ここで，細胞診へと進んでいく のだが，画像診断の段階でどのような組織型を予測す るかによって，その採取方法は微妙に異なってくる。

\section{2. ブレストピアで行っている FNAC の方法 ${ }^{81}$}

組織型を念頭に置いたFNACについて論じる前に 

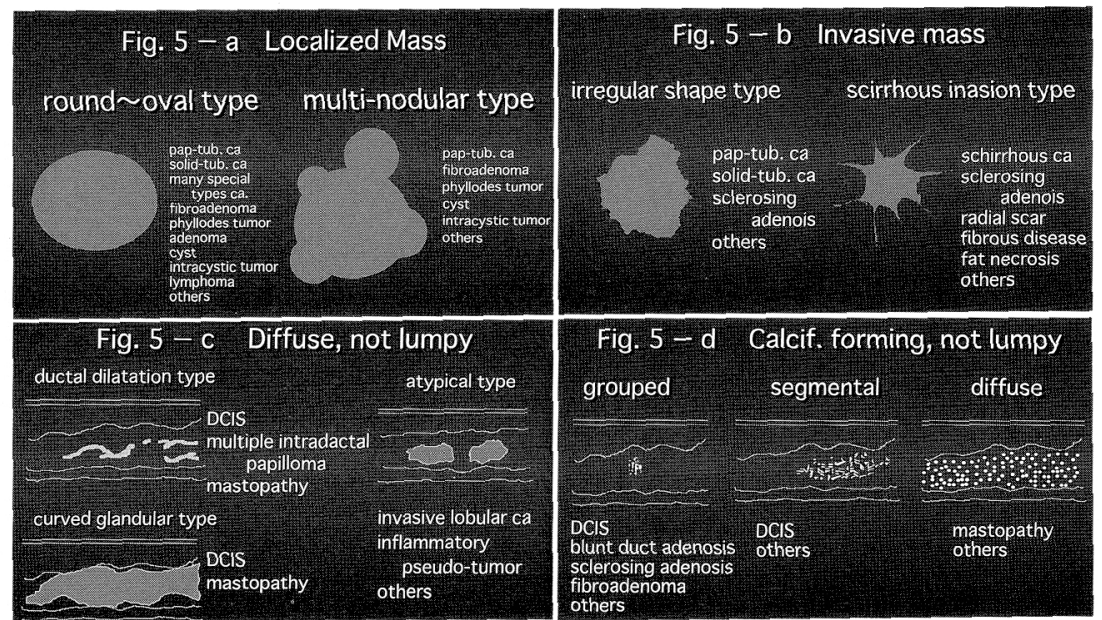

Fig. 5 Comparison of imaging patterns and histological types. a : well-demarcated tumors, $b$ : invasive tumors, $c:$ diffuse, non-tumorous, $d:$ calcification-forming, non-tumorous.

まず，著者が考案した簡便法によるFNACを紹介す る。触知，非触知に関わらず，全例で超音波画像下に FNACを行うことの合理性は，以下のデータに裏打 ちされている。ブレストピア開設時の 1991 年 6 月か らの 3 年 8 力月間に明らかに腫瘤を触知し, 触診下で の FNACが行えると判断した 325 件の腫瘤につい て，正確な穿刺の可能性について検討を行った。まず 触診のみで穿刺し，腫瘤に針が刺さったと判断した後 に超音波で針の位置を確認した結果，54 件（17\%）

で針が腫瘤に刺さっていないことが分かった。これら の症例については，その後，超音波誘導下に正確に腫 瘤を穿刺して細胞を採取した。これらの症例の特徵 は, 良性では線維腺腫や囊胞性腫瘤のようによく動く 腫瘤, 悪性では硬癌のように周囲の組織を巻き込むた 凶触診上, 実際の腫瘤径よりも大き々触れる腫瘤, さ らに良悪性に関係なく大きい乳房などであった。

\section{FNAC における臨床側の責任}

FNAC を行う際の臨床側の責任は，1）正確で安全 な穿刺，2）十分量の検体採取，3）適切な検体作製の 3つである。これらの条件を満たすために，ブレスト ピアでは活涩すべての FNAC 超音波誘導下に簡便 な方法で実施している。本法の特徴を以下に示す。1) 穿刺用アダプターや吸引用の特殊な道具は用いず，22 G 針を延長チューブで $50 \mathrm{ml}$ ディスポ注射器（女性 が最大の力で吸引をかけても引き抜けない大きさ）に 接続してマニュアルに行う。そのことにより，穿刺者 は細かい操作に専念し，吸引は助手に任せることがで
きる。さらに，針先端での組織の破砕を目的として， 吸引しながら, 針を小刻友に出し入れしたり, 回転さ せたり，さらにバイブレーター(電動歯ブラシのブラ シを外したもの）を針の基部に当てることもしてい る. 2) 対象病変の性状 (触知, 非触知, 囊胞性) $飞$ より 3 つ方法に分けている. 3）全例, 穿刺針の位 置を示す直角 2 方向の記録写真を証拠として残すこと である。

\section{4. 簡便法による FNAC の方法}

非触知腫瘤, 触知腫瘤, 囊胞性腫瘤などにより主に 3 つの方法に分けて行っている.

（1）超音波誘導下 FNAC (US-guided FNA, USGFNA)

腫瘤を触れない場合は，最初から超音波を用いて針 を誘導し穿刺する。

（2）超音波確認FNAC (US-confirmed FNA, USCFNA)

腫瘤を触れる場合は, 触診で穿刺した後に超音波で 確認をするもし，外れていたら超音波誘導下に針を 腫瘤に穿刺する。

(3) ダイナミック超音波誘導下 FNAC (Dynamic US-guided FNA, Dynamic USGFNA)

ほとんどの操作は上の 2 法と同様である。この操作 が他と異なる点は, ディスプレイ上で観察しながら注 意深く吸引を行い, 可能な限り囊胞液を吸引し, 最終 的に囊胞がどのような状態湾化したかを超音波画像 上で確認記録する点にある。従来, 囊胞性の場合, 単 
なる翼胞か囊胞内腫瘍かの鑑別を，吸引後触知するも のの有無を触診で確認していたものを，この方法では 超音波で確認するのだから，診断が明らかに容易かつ 正確になるままた，患者にもこの変化をディスプレイ 上でみてもらえるので, 病態の理解度が高まるという 利点もある。

\section{VI. 各組織型や腫瘍の形態を念頭に 置いた FNACの留意点}

ここでは，組織型を念頭に置いたFNACについて 主に留意点を実際の症例を提示して解説する (Fig. 6 $\mathrm{a} \sim \mathrm{e})$.

\section{1. 囊胞性腫瘍を推定する場合}

画像上，囊胞を疑っている場合は，当然ながら最初 に液を吸引する。もし, 吸引後に SOL の残存がみら れた場合は，超音波誘導下にその SOLを穿刺し吸引 する，初めから囊胞性腫場を考える場合は，まず，囊 胞内の腫瘍と思われる部分を穿刺し, 細胞を確保す る。その後に囊胞液を吸引する。その方が，腫瘍の性 状が確認しやすいし，腫癔の穿刺も容易である（Fig.
6 a).

\section{2. 限局性腫瘍を考える場合}

ここで最も重要なことは, 限局型の腫瘍では画像診 断で良悪性の鑑別が特漠隹しく，詔診することがあ り，FNACに診断を頼ってしまうことが多いことを 認識することである。したがって，穿刺する側は間違 いなくその腫演の顔となる細胞をきちんと採取するた めの最大の努力をする必要がある。

まず腫瘍の中心部分に針を進め，針先を小刻みに出 し入れしたり，回転させたりして中心付近の組織を破 砕し, 吸引をかける。これは, intracanalicular type の線維腺腫のように細胞成分の少ない腫瘍からできる だけ多くの細胞を採取するためである。次に，吸引し ながら針を少しずつ引き抜き，腫演の外縁近くで十分 な吸引を試みる。これは中心繊維化や中心溒死の目立 つ充実腺管癌では腫湟の辺縁近くの薄い層にしか生き た細胞がみられないことがあるからである(Fig. 6b)。

\section{3. 硬癌を考える場合}

硬癌を疑う時念頭㯰くことは, 細胞成分が小さ く, 少ないことが多いということと, やはり中心部分 は線維化していることが多く, 腫瘍辺縁近くからのし

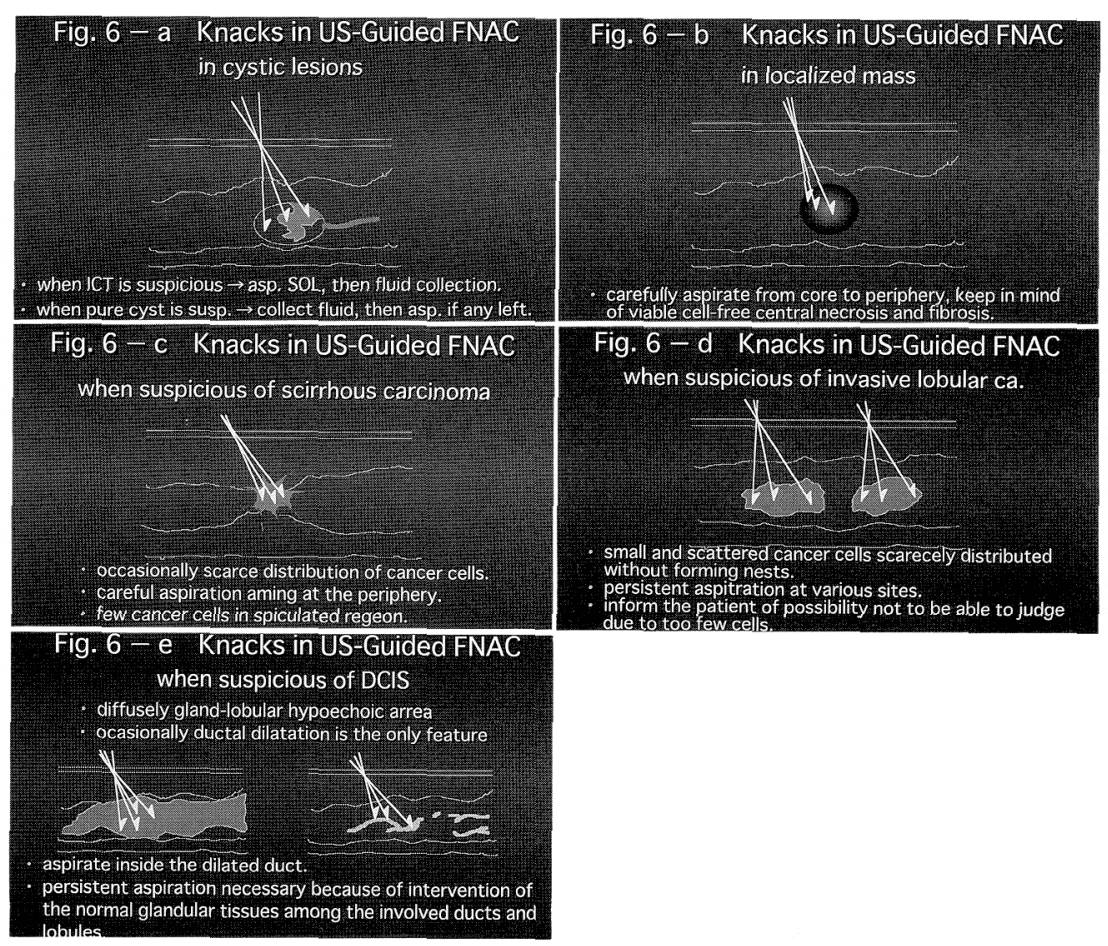

Fig. 6 Advisary notes on US-Guided FNAC. a : cystic tumors, b : well-demarcated tumors, c: scirrhous carcinoma, d: invasive lobular carcinoma, e: noninvasive ductal carcinoma. 
つかりした採取を試みることである。限局型との大き な相違は, 限局型では辺縁部の細胞成分は多いが，硬 癌では少ないことが多く,さらに組織が硬いので, 針先 での組織破砕を行いながらの採取を勧める (Fig. 6c).

\section{4. 浸潤性小葉癌を考える場合}

触診で硬結様のものを触れ，マンモグラフィでは明 らかな所見がみられなかったり, 注意深く観察すると 構築の乱れや左右非対称程度の所見があり, 超音波で はその部位に一致して低エコー領域が広がっているよ うな場合は，びまん浸潤性の小葉癌を念頭に置いてか かる.

この場合は，硬癌よりさらに小さな細胞が間質の間 を静かにびまん性に浸潤していることが多く, 細胞の 採集が非常に難しい. 疑わしいと思われるいくつかの 部位から，丹念に細胞採取を試みなければならない。 細胞が小さくまばらでおとなしいことが多いので，浸 潤性小葉癌を疑っている旨が細胞診判定側に確実に伝 わるような記載も必須である。また, 患者に FNACで 最終診断がつかないことがあり得ることとその場合は 組織を採取しての病理組織診断が必要になることを必 ず事前に説明する位の周到さが肝要である (Fig. 6d).

\section{5. 非浸潤性乳管癌を考える場合}

非浸潤性乳管癌は囊胞内癌を除くと腫瘤を形成する ことはほとんどなく, 乳管内での進展発育が中心であ る.超音波画像上低エコー領域が地図上に広がってい るような場合は，その領域の数カ所からの針を小刻み に動かしながらの丹念な FNAC が必要である. 正常 組織の中を走行する乳管または小葉腺腔の中にしか癌 細胞は存在しないことを念頭にイメージしながら吸引 を行うことが重要である．超音波画像上，乳管の拡張 像と乳管内での増殖像しかみえないこともあるが，そ の時は注意深く乳管内に針を刺して細胞や乳管内容液 を採取する，さらに，申込書に非浸潤癌を疑っている ことを明確に記載し, 細胞検査士に伝えることも怠っ てはいけない.ここでも，患者には良悪性の診断の難 しい病変であることと細胞診で診断が困難な場合は切 開生検などの必要性があることを予め理解してもらつ ておくことも肝要である (Fig. $6 \mathrm{e}$ ).

\section{6. 異常乳頭分泌の細胞診}

乳頭から血液を含む分泌液が認められる場合，その 診断はきわめて難しい. 近年の経乳管口的乳管内生検 法 (Intraductal biopsy of the breast, IDBB) ${ }^{9}$ や乳 管鏡（乳管内視鏡， mammoscopy）の考案 ${ }^{10)}$ などの 進歩によりかなり低侵襲的に適格な診断ができるよう
になったが，普及には少々時間がかかりそうである。 一般的には, 直接塗抹細胞診や乳管内洗浄細胞診が行 われているが，ほとんどが非浸潤性乳管癌のため細胞 自体がおとなしく，また乳管内での変性も加わって， 成績も良くない。 ちなみに当院における両者の sensitivity は扔の扔の $36 \%$ と $50 \%$ であった。乳腺細胞診 における今後の大きな課題である ${ }^{11)}$.

\section{Paget 病を考える場合}

Paget 病は乳頭乳輪部皮膚の真皮を中心に主に真皮 内で発育進展する乳癌である。一部は乳管内にも進展 する，乳房内に腫瘤を伴うょうな Pagetoid 癌は進行 していることが多いが, Paget 病の予後はきわめて良 好で, きちんと診断治療が行われると, ほほ $100 \%$ 完 治する。

臨床的には乳頭乳輪部皮膚の慢性湿疹様の症状がみ られる。その診断法は細胞診か組織生検しかなく通常 細胞診が行われる。この場合は擦過細胞診が行われる が, Paget 病の病理組織像を考慮すれば，表面を軽く なぞるような擦過では生きた Paget 細胞が採取でき ないこともある、筆者は, 摂子などを用いて皮膚表面 を出血が出る程度に削った上で擦過する。このこと で，偽陰性はほとんど予防できる。

\section{VII. 終わりに}

乳腺細胞診における組織型推定について, 乳癌専門 の臨床医の立場から特に画像診断の組織型推定の観点 から検討した。乳腺腫瘍は病理組織型にきちんとパ夕 ーン分類されているのだから, 複雑な画像パターンや 細胞像パターンを組織型パターンと照合しながら, ス テップを踏み, 診断するプロセスが正しい診断への最 も確実な近道であると思われる。

そのためには，画像診断や細胞診に携わる医療技術 者は, 乳腺腫瘍の組織型パターンをしっかり学びと り，常に組織型推定に則った抢互いにフィードバック をかけ合いながら診断学を向上させることが重要であ る.

\section{Abstract}

diagnosis of breast cancer has been rapidly advanced in Japan. Current diagnostic procedures, such as physical exams and open surgical biopsies, are being replaced by imaging diagnosis, less-invasive cytology procedures, and 
core-needle biopsies.

Cytological diagnosis has become more complex and advanced because of the increasing clinical demand for not only a differential diagnosis, but for indications as to the prefeved therapy and follow-up. In this context, consideration of the histological findings as fundamental characteristics of the morphological patterns of breast tumors has become important in both imaging and cytological, studies.

Based on the results of 12,000 breast cytological studies, the use of our diagnostic system to detect breast cancer at a super-early stage and the present status and problems of diagnostic approaches that are based on histological classifications were evaluated. Our procedure consisted of the morphological classification of breast lesions observed using imaging methods froma histological viewpoint. The most appropriate technique for obtaining a cytology specimen was selected based on the predicted histological type. We found that the accuracy of both imaging and cytological diagnoses can be inaeased by two-way feedback.

Diagnostic systems where free and open pathways among the imaging, cytological, and pathological sections, was present produced the highest diagnostic accuracy.

\section{文献}

1）難波 清, 蒔田益次郎, 山尾玲子, 谷脇紀子, 岡田健 二, 堀本沢子・ほか. トピックス第 1 回乳癌学会から； 超早期乳癌診断システムによる Tis および 0 期乳癌の 診断. 乳癌の臨床 $1994 ; 9: 56 \sim 57$.

2）難波 清, 蒔田益次郎, 水谷三浩, 青山英子, 松 敬
文，中原 浩・ほか. 乳がんの診断と治療〔ブレストピ アなんば病院]. インナービジョン 1997；12：8～39.

3）蒔田益次郎, 難波 清, 青山英子, 水谷三浩, 村田博久 ・ほか. 乳腺の腫瘤性性病変に対する超音波ガイド下針 生検の意義. 乳癌の臨床 $1996 ; 11 ： 785 \sim 792$.

4) Parker, S.H., Dennis, M.A., Stavros, A.T., Johnson, K. K. Ultrasound-guided mammotomy. A new breast biopsy technique. J Diagn Med Sonography 1996 ; $12: 113 \sim 118$.

5）渡辺良二, 難波 清, 古澤秀美, 白水光紀, 松 敬文 ほか．超音波ガイド下 Mammotomeによる乳腺生検の 工夫. 乳癌の臨床 $2000 ; 15: 229 \sim 232$.

6) World Health Organization. In: International histological classification of tumours. No.2. Histological typing of breast tumours, Second Ed. Geneva : World Health Organization, $1981 ； 19$.

7）日本乳癌学会・編. 臨床・病理乳癌取扱い規約. 第 13 版. 東京：金原出版, 1998 .

8）難波 清, 蒔田益次郎, 山尾玲子, 岡田健二. 簡便法に よる超音波ガイド下の乳腺穿刺吸引細胞診の試み、第 30 回日本癌治療学会誌 $1992 ; 27: 1487$.

9）難波 清, 坂元吾偉, 蒔田益次郎. 乳管内病変に対する 経乳管口的乳管内生検法一乳管内で診断された乳癌の 1 例を中心に．乳癌の臨床 $1989 ; 5: 606 \sim 615$.

10）難波 清, 霞富士雄, 渡辺 進, 吉本賢隆, 西 満正, 秋山 太・ほか. 異常乳頭分泌の鑑別診断. 外科治療 $1989 ; 61: 131 \sim 140$.

11）難波 清, 蒔田益次郎. 異常乳頭分泌を示す腫瘤非触知 乳癌の診断. 日本癌治療学会誌 $1993 ; 28: 1592$. 